\title{
Article
}

\section{From Socially Distant to Socially Engaged: Exploring the Soundscape and Material Environment of Guillaume de Machaut's Remede de Fortune}

Mahoney-Steel, Tamsyn

Available at http://clok.uclan.ac.uk/37960/

Mahoney-Steel, Tamsyn ORCID: 0000-0003-0037-7281 (2021) From Socially

Distant to Socially Engaged: Exploring the Soundscape and Material

Environment of Guillaume de Machaut's Remede de Fortune. Digital Philology: A Journal of Medieval Cultures, 10 (1). pp. 64-94. ISSN 2162-9544

It is advisable to refer to the publisher's version if you intend to cite from the work. http://dx.doi.org/10.1353/dph.2021.0003

For more information about UCLan's research in this area go to http://www.uclan.ac.uk/researchgroups/ and search for <name of research Group>.

For information about Research generally at UCLan please go to http://www.uclan.ac.uk/research/

All outputs in CLoK are protected by Intellectual Property Rights law, including Copyright law. Copyright, IPR and Moral Rights for the works on this site are retained by the individual authors and/or other copyright owners. Terms and conditions for use of this material are defined in the policies page. 
Tamsyn Mahoney-Steel

University of Central Lancashire

\section{From Socially Distant to Socially Engaged: Exploring the Soundscape and Material Environment of Guillaume de Machaut's Remede de Fortune}

Ostensibly a story about gaining confidence in love, Guillaume de

Machaut's Remede de Fortune has been explored as a summa of contemporary musical styles and a treatise on the memorial arts. ${ }^{1}$ It has also been examined as an important example of the use of citation and allusion in the fourteenth century because it incorporates references to Boethius' Consolation of Philosophy and Guillaume de Lorris and Jean de Meun's Le roman de la Rose. This essay enhances these studies by focusing on a particular aspect of the narrative: the use of soundscape and material environment to express the protagonist's emotional growth. After exploring key concepts such as soundscape, authorial self-presentation, and melancholy, it considers how sound is introduced and presented in relation to the narrator's emotional world and how music is woven through the narrative. An analysis of how sound and touch play a role in the narrator's interaction with Lady Hope leads to a discussion of the use of soundscape and material environment in the description of the Park of Hesdin and the festivities at the manor house. As this examination of soundscape and environment will show, Machaut chooses to use them as a means to convey the narrator's burgeoning confidence: he gives a minimal and clichéd description of the wonderful park when the narrator is mired in melancholy yet offers an elaborate, exciting treatment of the manor house after the narrator's confidence-building interaction with Lady Hope. The essay closes with a consideration of how the presentation of sound and material environment relates to Machaut's use of Boethius. In the context of the material turn within medieval studies, I argue that we can view sound and objects within medieval literature as media for the communication of ideas about narrative and character development and that this form of analysis sits comfortably with other lenses of interpretation. 
uillaume de Machaut's Remede de Fortune (henceforth Remede)
is a favorite among scholars and students of fourteenth-century
French poetry and music. Within its relatively short 4,300 lines there is much to explore and enjoy. The piece is interpolated with seven pieces of music representing a variety of styles from the time. Together, they reveal certain stylized attitudes toward the amorous interactions of courtly people and provide a lesson in the arts of memory. ${ }^{2}$ The piece also demonstrates how allegorical figures are used in an otherwise real setting, and it places itself within the wider canon of medieval literature through citation and allusion to works such as Boethius' Consolation of Philosophy and Guillaume de Lorris and Jean de Meun's Le roman de la Rose. Despite all these attributes, its enduring appeal is perhaps as much associated with these as it is with the comforting familiarity of the tale. The young and nervous narrator is in love but unable to declare himself to his lady; he appears socially inept and unconfident. Through an extended counseling session with the allegorical figure of Lady Hope, he learns the importance of self-reliance and comes to understand that, while he does not have power over the vicissitudes of Fortune, he does have a choice in how he reacts to the whims of her turning wheel. With a new self-assurance he returns and declares his love to his lady, not only winning her heart but also taking part in the social activities of the court. Yet despite the confidence he has found, he still displays endearing and relatable moments of anxiety and self-doubt.

Our ability to interact with and appreciate this tale has benefited from developments in the digital realm. The new hard copy edition by the Medieval Institute Press with a modern English translation by R. Barton Palmer is complemented by a free online version. The website The Works of Guillaume de Machaut: Music, Image, Text in the Middle Ages, produced at the University of Exeter under the direction of Yolanda Plumley, includes a section titled "Making and Using the Edition" by Uri Smilansky, which describes in detail how the music of the new edition was edited, accompanied by extensive examples of the music recorded by the Orlando Consort and Le Basile. New commercial recordings by the Orlando Consort and Marc Mauillon have also made the sound world of the Remede more accessible. Nearly all Machaut's complete works manuscripts are now freely available to view online in full color, and many of the anthology manuscripts containing his works are also digitized. ${ }^{3}$ This essay is a first step in an online project that will explore the sound and psychology of the Remede, adding yet another dimension to how the narrative can be encountered digitally. I will be working with composers and sound specialists to experiment with the 
soundscape of the Remede and its relationship to the emotional development of the narrator.

Here, I am not so much proposing an alternative reading of the Remede as I am asking readers to pay attention to its full bandwidth. ${ }^{4}$ Therefore, I examine the tale from the perspective of its soundscape and physical environment, showing how the narrator's emotional development and ability to engage in social activities manifest in his relationship to his rich sonic and material surroundings. Music is an important part of the Remede; and while I do not focus deeply on the structure or style of the interpolated pieces, I nonetheless emphasize that the social nature of music forms a part of how the narrator's journey can be understood. ${ }^{5}$ I pay particular attention to the descriptions of the Park of Hesdin and the life in the manor house, reading one as the antipode to the other in relation to the narrator's mental wellbeing. The interaction between the narrator and Lady Hope provides perspective on both the sounding and material aspects of the narrator's healing process. Finally, I comment on how an appreciation of the sonic and material aspects of the Remede allows us to think about Machaut's use of Boethius' Consolation of Philosophy.

\section{Sound, Self, and Emotion}

My argument in this essay relies on several interlinked concepts: soundscape, authorial self-presentation, and notions of mental health. The term soundscape, coined by R. Murray Schafer, has become increasingly important in medieval studies. It denotes our sonic environment: those sounds that reach us at any given moment. ${ }^{6}$ A soundscape, according to Schafer, "consists of events heard not objects seen," and he admits that this creates disadvantages when we are "in the pursuit of a historical perspective." 7 As medievalists, we must turn predominantly to the evidence of architecture, written sources (text and music), and images (illuminations, marginalia, and so on) to recover not only what medieval people may have heard but also what they particularly valued or disliked in their auditory environment. Emma Dillon, for instance, looks to music and lyrics for clues about how environmental sounds shaped and were shaped by music. ${ }^{8}$ In The Sense of Sound: Musical Meaning in France, 1260-1330, she discusses "a strange alchemy of circumstances-creative, economic, intellectual, and technological"-that led to a period of imaginative play with the sounding environment: ${ }^{9}$

$[F]$ or a few decades at the end of the thirteenth century and beginning of the fourteenth century in northern France, it seems that 
musicians, in collaboration with artists, intellectuals, poets, painters, and manuscript makers, were experimenting with the possibilities of sound, and the range of meanings it could convey. ${ }^{10}$

Machaut's poetic and compositional genius was forged in the crucible of these vibrant experimental years, when the ars nova not only allowed for experimentation with rhythm and greater subtlety of expression but also the complete reevaluation of the understanding of sound and meaning. The Remede is an example of how Machaut harnessed the possibilities of sound within his storytelling and referenced soundscapes and material environments that would have been familiar to his readers or listeners.

Other medievalists have also sought to unearth past sound worlds and explore their relationship with texts, environments, social situations, and thought processes. ${ }^{11}$ Sarah Kay and François Noudelmann, for example, remark that "Schafer's concept of soundscape has opened up new ways of listening, and theorizing about listening [. . .] by bending our ears towards sounds that are usually excluded from attention."12 Till now, the Remede's sound world has exclusively been understood in terms of its music. Yet its narrative takes place in an existing environment familiar to its contemporary target audience. In bending our ears to some of the extra-musical elements, both implied and described, we are able to infer a soundscape for the park and manor house and gain a deeper understanding of the narrator's emotional state.

Soundscape theory divides sound into three kinds: geophony, which comprises natural sounds from nonliving sources, such as weather; biophony, which encompasses the sounds of nonhuman animals; and anthrophony, which are sounds made by humans and human constructions. ${ }^{13}$ Sound in the Remede consists mainly of biophony and especially anthrophony. Within the narrative, sound can be divided into real-time direct occurrences and reported occurrences. The former includes the music, speech, and sounds that happen in the course of the narrative (such as direct speech). So the music happens in real time because even if we read the narrative quietly or read it aloud without singing the music, those songs are presented as taking place within the time frame of the narrative. Reported occurrences are ones that do not happen in the narrative time frame, as when the narrator describes the beauty of the lady's voice. There are also implied sounds, which can either be direct or reported. These include mention of activities that would necessarily involve sound (such as moving a table) or references to activities such as weeping, crying, or moaning (which in context could be read from 
an emotional standpoint but would usually involve sound). The direct and indirect sounds within the narrative are also linked to the shifting presentation of the author, defined by Kevin Brownlee as clerkly teacher, poet-creator, and narrator-protagonist. ${ }^{14}$ Understanding these shifts can aid us in perceiving the role of sound, enabling us to differentiate between the narrator's role as the teller of the story that we read/hear and the narrator as the protagonist within the text, who is heard and spoken to by other characters. This last point can be understood in terms of diegesis. While both the direct and reported sounds can be read as diegetic, there are also moments when the narrator appears to speak to or perform for the reading or listening audience, creating extra-diegetic moments.

No discussion on Machaut and his work can take place without acknowledging the complexity of his authorial persona. The notion of medieval authorship is often viewed as communal and is intricately linked to how existing material was reused, through either direct citation, more subtle allusion, or the reimagining of certain ideas and tropes. It was common for large portions of music or text to be borrowed from one context and reused in another. ${ }^{15}$ According to R. Barton Palmer, premodern literary composition "was always already defined by a process of appropriation." 16 While Machaut was not the first to assert his authorial identity, he went far further than those who came before him in establishing the author as a controlling creator figure, so much so that Palmer regards him as a "liminal figure" who stands on the cusp of literary modernity and sees his work as a precursor to the modern novel. ${ }^{17}$ Machaut did not dispense with citation and allusion as tools for crafting his literature and music. Instead, he subsumed the borrowed material under his authorial identity through the insertion of his literary persona at the forefront of his narratives and the intentional collection of his oeuvre in complete works' manuscripts. This placed him front and center as both protagonist and creator and leads us to question to what extent the lyric $I$ of his narrative poems is a literary device or an autobiographical account.

As I have noted, Brownlee observes that Machaut plays several roles within the Remede, switching among the didactic function, in which he initially asks us to listen; the poet, who creates and gives us extra-diegetic and retrospective information; and the lover-narrator, who experiences the world of the tale. This plural identity that confronts the reader finds its highest expression in the Voir dit in which Machaut presents himself as the protagonist in a love affair with a younger admirer, TouteBelle. As Deborah McGrady suggests, in placing himself centrally in 
this pseudo-autobiography, he also emphasizes his role as poet-creator, compiler and steward of his artistic output who attempts to resist an audience that may pick apart, scorn, or repurpose his work. ${ }^{18}$

We can view neither the Remede nor the Voir dit as reliable autobiographies, and this is not merely because of the fantastical and allegorical elements. Machaut's shifting self-presentation also suggests that we should not read these tales as memoirs. That said, I do not believe there is any reason to doubt that he was drawing on real emotional experiences. These works gain credibility as we recognize that the author is as preoccupied with his writing process and his reception as he is with his beloved. This is not merely a lover's journey; it is a writer's too. In both stories, the narrator's artistic output is improved or revived by the intercession of a lady. McGrady observes that in the Voir dit he is "more enthusiastic about the artistic creativity [Toute-Belle] stirs back to life."19 The Remede, meanwhile, chronicles the narrator's encounter with and lessons from Lady Hope, who both revives his confidence and extends his compositional abilities. These dual preoccupations with romantic love and creative ability exhibit a depth of personality that suggests a certain verismo. Hence, we can view the portrayal of emotion as, in some regards, honest, even if the tales are partly fabrications.

In writing about the relationship in the Remede between the narrator's emotional journey and the soundscape of the narrative, I have necessarily been drawn to considerations of how noise, sound, and music relate to issues of wellbeing and mental health. It was tempting to draw comparisons with modern medicine, pathologizing the narrator as suffering from social anxiety disorder, general anxiety disorder, depression, or cyclothymia. However, I resisted this urge; as Joanne Edge notes, it is not our "job to impose modern categories of thinking onto past cultures." ${ }^{20}$ Indeed, the modern medicalization of both mental and physical conditions can hinder our engagement with medieval accounts. Like Edge, Richard Godden and Jonathan Hsy have noted that uniform concepts of disability or illness, as we understand them, did not exist in the Middle Ages, and they argue that pathologizing conditions "as in need of treatment or cure" limits our ability to perceive accounts of physical or mental impairment or illness on their own terms. ${ }^{21} \mathrm{I}$ do, however, acknowledge that I was drawn to the Remede because of an interest in mood disorders and the familiarity of some of the narrator's "symptoms." This interest, combined with my research into music and sound, led me to recognize that the Remede is in part a story of improving mental wellbeing and that the narrator's journey is notably played out through his relationship to his sounding and physical environment. 
Rather than attempting to characterize the narrator according to any modern frameworks, I have come to view the Remede therapeutically and as a potential vehicle for adding depth and counterpoint to discussions on mood and emotion.

Melancholy and lovesickness are conditions that are somewhat medicalized within medieval writing. While Machaut himself does not explicitly discuss love in medical terms, he does show the lover exhibiting the classic symptoms of love qua sickness. Most notably, after singing the complaint Tels rit au main, the narrator describes a catatonic state in which he is barely able to move or speak..$^{22}$ Medieval physicians grappled with the question of the locus of emotion. Their major sources for this debate were Galen, who saw emotion as something that imprints first on the soul before affecting the body, and Avicenna, who regarded the body as the seat of emotional experience. ${ }^{23}$ Galen was frequently favored for his view on emotion because he saw it as an alternative to the physical causes of illness:

In one famous case he treated a young woman who seemed to exhibit the signs of physical illness but who, upon closer examination, revealed no organic pathology. After eliminating any possible humoral explanation, Galen identified the real, emotional cause of her somatic symptoms: a hidden love interest. ${ }^{24}$

Just as the humors (black bile, yellow bile, phlegm, and blood) could cause illness when imbalanced, so, too, could emotions. It was therefore important to strive for emotional equilibrium. The "cure" for Machaut's narrator is not a medical regimen to balance his humors nor the attainment of his romantic goal (though he is successful). Instead, the "remedy" of the Remede is what we might call a form of proto-talking therapy. Taking a cue from Boethius' Consolation of Philosophy, in which Lady Philosophy counsels acceptance of fate rather than lamentation, Machaut's Lady Hope urges the narrator to be self-sufficient instead of being at the mercy of Fortune's whims. Balance, in other words, means not being excessively affected by the turning of Fortune's wheel.

\section{Setting the Tone with Sound}

From the outset of the Remede, Machaut hints at the importance of sound, noting that one who wishes to learn should attend to twelve matters:

Cil qui vuet aucun art aprendre A .xij. choses doit entendre. 
The man who thinks to master any art

Must attend to twelve matters. (11. 1-2) 25

The word entendre has an ambiguity similar to that of the modern English attend and can mean "listen" or "understand." While the narrator, in clerkly mode, explains these twelve matters, it is clear that, qua protagonist, the only thing he seems able to devote himself to with any sincerity is his obsessive, unrequited love. The lady is introduced in line 51 and from here until line 430 he extols her virtues, describing how loving her also ennobles him and improves his character because he uses her exceptional demeanor as a guide for his own. Sound is included in this section by means of what could be termed a blason de la voix feminine (emblazoning of the female voice). A blason du corps féminin (the emblazoning of the female body) is a trope of courtly love literature (found in, for example, Le roman de la Rose) and usually involves a poetic, codified description of a lady's physical form. Machaut explicitly rejects this trope in favor of emphasizing the pleasing qualities of his lady's voice as well as the moral worthiness of her speech.

This is the setting-off point for the narrator's emotional journey. He starts from a position of isolation, presenting himself as a thinking and knowing being solely in relation to his lady. While he claims to learn from her, he cannot truly do so because the process is not didactic. At the very beginning of the text he suggests that learning takes place under the tutelage of a master whom one must honor, obey, and serve, which implies a teacher-student relationship. Later we read of his interaction with Lady Hope, who employs a Socratic style to teach the narrator. However, when he initially describes his relationship with his beloved, he appears only to observe her good qualities and is quite unable to speak to her when she does question him. Hence, there is no reflection or mediation of the mental improvement that love has supposedly brought to him. He is at once socially and philosophically impoverished; indeed, his one recourse to exempla in this first section is bookended by the wisdom of Solomon (which he claims he does not have) and the perseverance of Socrates (which he also believes he does not have). Reflecting this lack of social and philosophic riches, his soundscape is likewise entirely situated around his lady. Hence, his only description of sound is the blason de la voix féminine. Moreover, there is no context or environment for his hearing her voice. For the reader/audience it is disembodied, abstract, and secondhand. 


\section{The Role of Music}

Music enters the narrative because the lady's qualities inspire the narrator to compose a lay about his feelings, Qui n'aroit autre deport. This is the first of seven notated pieces that take up nearly a quarter of the line length of the Remede. The Remede has also been regarded as a summa of contemporary styles as well as a pedagogical experience for the narrator who is learning the memorial arts. ${ }^{26}$ Music allows the narrator to express the depth of his feelings, particularly in the first half of the tale, and demonstrates his emotional development in the latter half. Yet it has an equivocal role, which may point to the negative as well as the positive aspects of sound in relation to the narrator's psychology. The first two pieces, the lay and the complaint, are far longer than the other notated pieces. Indeed, of the first 1,607 lines, more than half are given over to these two pieces; the rest of the lines are narration, with no direct speech. ${ }^{27} \mathrm{We}$, as audience, are as trapped as the narrator in his painful world of love misery, in which the only themes are the perfection of his lady, his unspoken love, and the terrible whims of Fortune. Seen as a whole, the lay and the complaint constitute nearly 20 percent of the total lines of the narrative, and a huge proportion of the overall notated lyrics (about 84 percent). ${ }^{28}$

In this light, Lady Hope's intervention after the complaint, in which she counsels him on managing his emotional response to the perceived whims of Fortune, is not just a matter of healing the narrator but of curtailing an inappropriate level of self-absorption. For while the Remede may well be a collection and even celebration of various musical styles, the interposition that Hope enacts suggests that we can have too much of a good thing and that the narrator must compose in a manner that brings joy and connection within his social sphere. The interaction is one-sided: the narrator is singing at us, as audience, rather than making music for those in the world of the story and inviting our empathy. Speaking of the lay, he says, “Ce lay qu'ö̈ m'avez retraire” ("This lay you've heard me recite" 1.682 ), implying that it was an extradiegetic performance for us rather than reporting it as an event that happened within the narrative.

Only when a written copy of the lay falls into the hands of his beloved does the story start to move. This is the first time that sound and a physical object intrude into the narrative as indisputably diegetic components, and they profoundly change the narrator's world. The lady, finding the lay, asks the narrator to read it aloud, and we are catapulted from the abstracted and secret world of the poet's internal desire to an 
in-person interaction with the lady. He obliges, albeit awkwardly and shamefaced, telling the reader that he read it to her; he specifically says read-le $\ddot{u}$ - which may encompass singing but is unclear. ${ }^{29}$ The fact that this exchange occurs through the mediation of a lay is a telling choice. While as a form it demonstrates the virtuosity of the composer, it is perhaps one of the least social or interactive forms of music: each of the twelve stanzas has a different meter and music, and there is no repeated refrain. This means that there is no opportunity for participation through dance, no chance to join in the singing, and no polyphony. The lay therefore suggests the narrator's social isolation. ${ }^{30}$ It is a catalytic moment in the story, however, because when lady asks who wrote it, the narrator, unable to confess or to lie, leaves in silence, propelling him toward his later meeting with Lady Hope. Further, the exchange involves no direct speech, and even the lay is only reported as being read. Rather than telling us he wrote the piece and then placing it within the narrative as a performance to the lady, Machaut's narrator chooses to present it first to the reader/listener and then relate that he recited it to her. This distances both narrator and audience from the sound and the environment of the lay's reading, subtly reemphasizing his social awkwardness and isolation.

If the lay expresses the narrator's aloofness, the next piece of music, the complaint, epitomizes it. Finding a deserted garden, the narrator sings Tels rit au main qui au soir pleure, blaming Fortune and lamenting her vicissitudes. The complaint has a gorgeous melody full of descending motifs that mirror his weeping and alternating pitches that represent the turning of Fortune's wheel. This piece of music is more repetitive than the lay. Yet the repetition still does not have a social function; instead, it serves to elucidate the narrator's emotional state. Each stanza has the same music, yet as with the lay there is no common refrain so that others can join in. At thirty-six stanzas long, the complaint would take nearly an hour to perform-an exhausting tour de force for any singer. Its melody is hauntingly beautiful, yet is difficult to listen to repeatedly for nearly an hour, and certainly serves to articulate the intense melancholic rut into which the narrator has descended. ${ }^{31}$ The repetition of the music is further enhanced by repeated ideas, motifs, and alliteration in the text, which reiterate the narrator's depressed emotional state and lack of hope. Elizabeth Eva Leach notes that a full performance would likely be "extremely boring" and that such a self-indulgent song was "intended to be ridiculous" to highlight the emotionally unstable state of its composer. ${ }^{32}$ 
It speaks to Machaut's particular brand of genius that he was able to compose a piece that is aesthetically pleasing yet, through its absurdity, still communicates to the reader/listener the discomfort of the narrator's emotional state. Tels rit highlights the intractable situation of the protagonist: he laments the effects of Fortune on his life, yet this very process of lamentation is what brings him pain. Lady Hope will later show him that he has control only over his response to the turning of Fortune's wheel; as long as he continues to complain, he is caught in its machinations. The aesthetics of the music is entangled with the narrator's mental state and the cyclical nature of Fortune's operation. The music can stop only when he reaches the point of collapse.

The remaining pieces of the Remede are all considerably shorter and far more social in nature-either because they happen as an interchange between two or more people, are polyphonic, contain a refrain, or all of the above. Lady Hope arrives after the complaint and finds the lover in a state of collapse. After counseling him for a while, she sings him a chant royal, Joie, plaisence, et douce norriture, which extols sufficiency as well as the idea that loving truly brings only a pleasant form of suffering. Its theme contradicts the narrator's perceived torment and so does its style. While the narrator has communicated his feelings through lengthy pieces, including the musically complex lay, Hope's chant royal is shorter, with a smaller range, and its melody moves predominantly by step, eschewing large intervals. Hope's philosophy of self-reliance and sufficiency is conveyed by a simpler sound world, yet she is also meeting the narrator on his terms by singing an older-style monophonic piece. By contrast, the next piece that Hope sings is more complex because it is polyphonic. The ballade, En amer ha douce vie, reiterates the idea that love's pains are a good illness. It can be seen as a preparation for the narrator to reenter the world because the four lines would require multiple musicians to realize it and the refrain hints at the possibility of others joining in. ${ }^{33} \mathrm{He}$ proves his readiness by committing this song to memory and, after Hope leaves, composes his own four-part ballade, Dame, de qui toute ma joie vient.

Once the narrator has rejoined the courtiers outside the manor house, he takes part in the dancing. Earlier he had referred to a group of ladies and gentlemen who were playing the game "Le roi qui ne ment" (The king who doesn't lie), yet his only reason for remarking upon them was the anxiety of not being overheard reading the lay. Now he recounts his joy in seeing and particularly in hearing them: 
Dames, chevaliers, et pucelles,

Et d'autre gent grant compaingnie,

Moult joieuse et moult envoisie,

Qui dansoient joliement.

Quant je les vi, moult m'esjoÿ,

Et plus, quant je les entroï.

Ladies, knights, and maidens,

And a great company of others as well,

Who were quite jolly and full of fun,

Dancing happily away.

Noticing all this, I felt quite happy,

Even more so when I heard them. (11. 3362-3370)

The lady prompts the narrator to sing a virelai, Dame, a vous sans retollir, for the company to dance to. Both Judith A. Peraino and William Calin have noted that this moment "marks his reentry into the social world and the regaining of his identity. Thus, the virelai represents a newly found voice." ${ }^{34}$ The virelai also signifies through its form that the narrator is more socially engaged. A piece with roots in dance forms, it connotes communal activity, and the repeated and catchy refrain suggests participation through singing. ${ }^{35}$

The final musical interpolation is the rondeau, Dame, mon cuer en vous remaint. This is, once again, a song the narrator creates and sings alone, but the mood is quite different from the first two pieces. Again, polyphony and repeated refrains suggest a social or communal performance, and the sentiment (of his heart remaining with his lady) bespeaks the happiness and ease the narrator feels, even when he takes leave of her.

\section{Hope's Intervention}

Lady Hope's intervention, which occurs after the long complaint, offers relief not only for Machaut's protagonist but also for the audience/ reader. Her arrival marks the end of the complaint's rambling dirge and returns both narrator and reader to the locus in which it was sung. Hope's presence reminds the narrator of sunlight, and she also exudes a delightful fragrance (11. 1540-1558), both of which hint at the beautiful garden in which he is reposing but that he has forgotten in his distress. Her subsequent teaching underlines the importance of personal interaction for both wellbeing and learning. She brings sound and touch to the narrator as well as a new and more positive form of silence. 
Her words, which revive him, are the first instance of direct speech, yet the narrator is still unable to reply for quite a while. Up to the point of his reply, he is a contradictory character for the reader/listener, for he is both mute and garrulous. As our guide to the story and the singer of the lay and the complaint, he is excessively communicative of his feelings. For this reason, it can be surprising to learn that he does not actually speak until the midpoint of the story. But within the story, the reading of the lay is a reported event; and when he leaves the lady, he is still unable to speak. Within the text of the complaint, he recounts that "la parole m'en tarist" ("words dried up in my mouth" 1.1266) and his five senses were "tost maté" ("completely bewildered" 1.1279). Just after singing, he tells us that "Aussi fui com tous desvoiez / De scens, de memoire, et de force / Et de toute autre vigour" ("I found myself drifting far away from reason, memory, strength, and all my other faculties," 11. 1490-1492). In line 1561 he is able to let out a moan and a sigh but is still rendered speechless with heartache (1l. 1567-1568). Not until after Hope sings the chant royal and speaks to him further, urging him to reply, does the narrator find his power of speech return. He even goes as far as to remind us that, while he is speaking to us now, he had been unable to speak within the context of the story:

Tout einsi le tres dous parler

De li, quant je l'ö̈ parler,

Me remist en cuer la parole,

Dont ci presentement parole,

Car de tous poins perdu l'avoie.

Lors parler, si com je pooie.

In the same way, the very sweet words

She spoke, as I heard them uttered,

Returned to my heart the power of speech,

Which I'm making use of now,

But had at that time completely lost.

So I spoke up, now able to do so. (11. 2121-2126)

Hope's words are sweet, as is her manner of speaking, which is described as "clear and soothing" ("clere et seinne" 11. 1605 and 2105), like her singing voice (11. 1978 and 2850). By contrast, Fortune has an "arrogant tone" ("fiere vois" 1. 1192). Just as notable are Hope's act of questioning (which requires a response) and her placement of the ring on the narrator's finger. He notes feeling its coolness (1. 2101). The conferment of the ring marks a moment of physical engagement and in- 
volves a worldly object (despite Hope's otherworldly origins). That she demands engagement through questions is important. Her teaching is necessarily Socratic. Whereas the narrator had claimed to learn from his lady, holding her up as a paragon of courtly behavior, he was unable to answer her questions and therefore could not truly learn.

A further change that Hope brings about is a beneficial form of silence. Before the narrator speaks with her, silence accompanies his moments of profound negativity and loss of faculties. When Hope performs her chant royal, he falls into a gentle doze but remarks that he is still able to listen and absorb her teachings. Jody Enders notes that this is an important moment because he is emulating those trained in the memorial arts: "Just before she begins her "chant nouvel" (the "chanson roial"), the Lover falls into a trance-the classic mnemonic state." 36 After Hope leaves, he again takes the time to be quiet and ruminate on her lessons, committing them to memory.

\section{Hesdin's Unremarked Wonders}

Before the narrator encounters Lady Hope, he tells us that he wanders into a park, which he names as Hesdin. This is first point in the narrative in which we hear of anything other than the narrator's feelings or the lady. He briefly describes some of the pleasures of the park:

Et quant j'eus mon vueil assevi

D'entrer ens, et tous seus me vi,

Le guichet fermai au verrueil.

Si m'en alai parmi le brueil,

Qui estoit si biaus qu'onques mais

$\mathrm{Ne}$ vi, ne ne verrai jamais

Si bel, si gent, si aggreable,

Si plaisant, ne si delitable.

Et les merveilles, les deduis,

Les ars, les engins, les conduis,

Les esbas, les estranges choses

Qui estoient dedens encloses

Ne saroie jamais descrire.

Entering the place, as was my intention, And observing I was all by myself, I closed and locked the wicket.

And I strolled through the shrubbery,

Which was so beautiful I'd never seen

The like, and never will, none other 
So attractive, so elegant, so agreeable,

None so pleasant or delightful.

And I'd never be able to describe

The marvels, the delights,

The artifices, the mechanical devices,

The piped-in water, the diversions,

The strange attractions the garden contained. (11. 805-817)

This description of Hesdin would no doubt have been a moment of shared delight for Machaut's audience; for not only was this park real, but it was a place of unique wonder and was popular with his aristocratic patrons. Owned at the time by the duke of Burgundy, Odo IV, it was frequented by the royal court and known for its extravagant ornamentation, which included delights such as mechanical monkeys covered in badger fur and featured fountains and organs. ${ }^{37}$ The narrator does not, however, provide us with an extensive description of the park, its visual delights, or its soundscape. Elly Truitt argues this represents a literary trope and a lack of knowledge on the part of Machaut:

Given the elaborate and extraordinary nature of the automata at Hesdin, it is surprising that Guillaume, as a casual visitor, did not describe them in more detail. Instead, the Lover says only that he could not possibly describe them all. The indescribable is a literary trope, but it also may be a factual claim due to the hidden mechanisms of the automata. ${ }^{38}$

Truitt is probably correct that Machaut himself had not seen the internal mechanisms, though he doubtless saw the actual automata in operation. ${ }^{39}$ She is also right to note that the indescribable is a literary trope, a kind of hyperbolic omission designed to tease an audience's sense of wonder. But it serves another purpose, too, for later in the narrative Machaut's narrator describes far more mundane objects and sounds in greater detail; he also describes a great range of musical instruments that accompany the banquet. The omission of any greater description of the famous and beloved park not only engages the imagination of an audience that is probably familiar with its appearance but also shows how disconnected the narrator is from his surroundings: he is in such a state of melancholy that he cannot even be truly engaged by the fabulous Hesdin. This makes the contrast between the narrator's behavior now and later even starker. Further, the lack of description of Hesdin fits with Ender's argument that the Remede is a work in which "the musicopoetic significance of memory" is "preeminent." 40 At this 
stage, the narrator has not encountered Lady Hope and received her instruction, a significant theme of which is the importance of cultivating the memorial arts. His lack of descriptive ability is therefore indicative of how overpowered his senses are: he cannot fully commit the scene to memory or offer anything other than the most generic description. He admits that the park contains entertainments of every possible kind"En l'air, en l'iaue, n'en la terre" ("In the air, in the water, or on the land" 1. 820) but refrains from offering any details of what these might be.

The soundscape of Hesdin, for an audience in the know, would have been part of the wonder, combining biophony and anthrophony in a manner that could have been heard nowhere else in medieval Europe. The landscape had been extensively reshaped into an aristocratic playground and even the "natural" elements were the product of human artifice. Fallow deer, reintroduced to northern France only in the late eleventh century, were primarily kept in enclosures in private game parks. ${ }^{41}$ The distinctive bellowing (sometimes called burling) of the bucks during the mating season would have been part of Hesdin's biophonic landscape. ${ }^{42}$ The park was home also to what was likely the first managed heronry in northern France; and while herons were native to the area, Hesdin's herons were probably kept in "a structure with a door or a gate," thus concentrating and multiplying their harsh cries in one place within the park. ${ }^{43}$ Alongside the biophony exaggerated by human artifice, the automata were unusual parts of the anthrophony. Those at Hesdin were "the first recorded instance of automata that were built, rather than designed, in the Latin West." ${ }^{44}$ With the elaborate fountain and bellows-operated organ, the Hesdin soundscape would be unique and memorable.

It is worth reemphasizing Hesdin's reality. Machaut often included real places and people in his work but incorporated fantastical elements into them, such as the appearance of Lady Hope in this tale and that of Venus in the Voir dit. Nevertheless, there is a strong sense that he is evoking familiar places that would both delight his audience and ground his stories in a physical and sounding reality. Once Hesdin is introduced into the narrative, it brings the world the narrator inhabits into sharper focus as a material and sonic phenomenon that had likely been touched and heard by those enjoying the Remede. That Machaut's narrator, in his distress, eschews these delights in favor of a fountain that is overgrown and with no clear path, might not only tease and surprise a reader but underscore the mental distress of the protagonist. 


\section{Delight in Simple Things}

Compared with the section of the story that describes Hesdin, the section in which the narrator returns to the manor house demonstrates a significant augmentation in his descriptive skills. The reader/listener is first made aware of this as the narrator leaves the garden. He remarks that no one could have followed him,

Qu'en riens n'i estoit depassee

L'erbe poingnant, et la rousee,

Clere et luisant seur l'erbe drue,

N'estoit pas encore abatue.

For the sharp-bladed grass was nowhere

Tramped down, and the dew,

Clear and shining on the greenery,

Had not been disturbed. (11. 2977-2980)

Noticing the dew is quite a turnaround given his earlier inability to recount the wonders of Hesdin. Indeed, he marvels at noticing the birds singing, admitting that his senses had been too dulled by sadness to notice them. Once he has returned to the manor grounds and sung the virelai for the dancing courtiers, his world continues to be detailed in sound and appearance. Another lady sings a refrain, which marks the first time we are directly told of another character, besides the narrator, his lady, or Hope, singing or speaking out loud. And when his lady takes the opportunity to engage the narrator in conversation, he eloquently tells her everything, admitting to composing the lay that she had originally found and confessing his love, which she graciously returns.

If we return to the start of the tale, we see that the narrator's descriptive powers were distinctly clerkly, drawing on references to biblical and Greek figures to situate his understanding. His description of the lady, while lengthy, employed very standard tropes, leaving us with a general impression that she is praiseworthy but offering little detail about her. Even the blason of her voice and speech gave us no more than a generic sense of virtue. Now, toward the end of the tale, while we do not get any further description of the lady, we do see her act and hear her speak directly. This results in a more fully realized sense of her character. The self-assurance the narrator has mentioned earlier is demonstrated by her telling him to sing and instructing those gathered to return to the house. We also witness her kindness: she realizes that the narrator is flustered, and she covers this by greeting him quickly and leading him to dance. Yet she is humble; even after the narrator explains that he wrote the lay 
for her, she asks him to confirm this and finds it hard to believe. In these few moments, we glean far more about her good character than from the narrator's earlier excessive lyricism. ${ }^{45}$

Once the narrator is assured of his lady's heart, his world becomes filled with intricate visual detail and a variety of sounds, most of which constitute a social and material anthrophony, with some details bordering on the mundane. There is also a great deal of movement in his environment, with activities described that would necessarily produce sound. For the first time, he chats with other people, who ask him for news. He keeps his love a secret, as the rules of stylized poetic love dictate, but appears to have no objection to the company. Returning to the house, he is eager to bombard us with detail. Whereas before his surroundings had been dull and muted, now they are alive with detail. His description of a chapel becomes a cinematic experience, as he describes mounting the staircase and engaging in prayer. Within this he reports how finely the chapel is painted; but because the description is bookended by activity (11. 3891-3909), we get the sense of his eyes sweeping across the room as he engages with its purpose.

After mass, we are drawn immediately from the chapel by the sound of trumpet in another part of the building, and we look through the narrator's eyes as the servants rush hither and thither. Reading about him in the period before he had rejoined the group of ladies and knights at the manor, we would have been forgiven for thinking that the place was sparsely populated. Now we have the impression that it would be hard to traverse any part of it without bumping elbows with scurrying messengers and stable boys, with musicians in fancy dress, with elegant ladies and gentlemen. Benches, trestles, and tables are set, bringing with them the implied sounds of wood banging against wood, scraping against stone floors, or more softly thudding onto the carpets that are also being laid out. While Machaut does not describe every single sound, he gives us a good sense of how noisy the scene is. The busy servants communicate loudly in an assortment of tongues:

Braire, crïer, et ramonner

Et l'un a l'autre raisonner,

François, breton, et alemant,

Lombart, anglois, oc, et norment

Et meint autre divers langage,

C'estoit a oïr droite rage.

Yelling, shouting, and pushing brooms,

Chatting with one another 
In French, Breton, and German,

Lombard, English, Occitan, and Norman,

And many other odd tongues,

And this was quite a babble to hear. (11. 3923-3928)

The servants are busy slicing bread, getting platters ready, scrubbing off crumbs, washing their hands. The scene is full of activity and noise:

C'estoit merveilles a veoir.

Car il menoient moult grant noise.

That was a marvel indeed to witness.

For they made a great deal of noise. (11. 3940-3941)

Furthermore, all of this happens in the time space between when the ladies and gentlemen leave mass and return to their rooms to change for dinner. Hence, we get the sense of a great deal of bustle in a short period. During the meal, minstrels play, sporting elaborate hair styles and clothing. Machaut's narrator treats us to a list of all the instruments being played (11. 3960-3988). It is hard to say whether all of them would usually have been part of the same ensemble, but the extensive and impressive list fits with that narrator's enhanced ability to notice his surroundings. He also draws our attention to the games being played and to a knight calling for wine and spices. Later, when the company reassembles, the narrator describes jousting and other merriment.

For some readers, these busy scenes may evoke the charivari. Traditionally, charivaris were noisy protests, usually against an inappropriate marriage, in which participants "ran amok, hurling dung, smashing down doors and polluting wells with salt." ${ }^{46}$ Noise often came in the form of pots and pans being banged. Here, too, we have the clatter of kitchen implements and people running to and fro. Yet this is an ordered and happy commotion in which each participant has an organizational purpose: it could be termed an anti-charivari. The inclusion of this scene could therefore confer a blessing on the union. Regardless of whether this was Machaut's specific intention, we can appreciate more generally that the environment and soundscape of the Remede are significant parts of the expression of joy that this story ultimately conveys. All of this activity in and around the manor house serves to demonstrate how Hope has reawakened the narrator's senses. The lady's bestowal of her love appears to make him more aware of and engaged with his surroundings, yet even before this he notices little details that are shared with the reader/listener. And when we compare the minutiae of the description 
of a cheesecloth being removed with the lack of detail provided for the wondrous Park of Hesdin, we can truly appreciate how much the narrator's senses are enlivened by his newfound happiness and confidence.

\section{Boethian Philosophy and Mundane Joy}

The Consolation of Philosophy is a striking semi-autobiographical work. Boethius, facing a very real death sentence, created an allegorical work to cope with his terrible situation. It opens with the Muses lamenting his fate, but they are sent away by Lady Philosophy, who arrives and deplores the self-obsession of the sad songs. Instead, she argues that Boethius must reject the things of the world and find solace within himself. The work was frequently cited by medieval authors. Machaut drew extensively on the Consolation, most notably in the Remede, Le confort d'ami, and his Prologue. ${ }^{47}$ Yet transporting this work, whose concern was stoicism in the face of mortality, into the realm of love stories may seem like a curious move. Sarah Kay and Lewis Beer, for example, note the grounded and youthful nature of the Remede in which the narrator does not leave "behind the untrustworthy joys of this world in order to tend to his soul." 48

Machaut certainly wrestled with his use of Boethius but by no means glossed over the problems of balancing the different demands put upon him by his clerkly background and position within the church, his duty to his patrons, and his own artistic integrity. Rather than avoid these complications, he often wove them into the fabric of his characters and narratives, which is one reason why we feel his authorial presence so strongly. Calin sees Machaut as trying, in the Remede, "to resolve conflicts exposed in Le roman de la Rose between the Boethian and courtly philosophies." ${ }^{49}$ He notes that Lady Hope condemns the narrator for his attachment to Fortune but does not advise him to abandon love as the character Raison did to the Rose's lover. Calin believes that Machaut's narrator can influence his fate because "Fin' amor, not subject to Fortune, not of the same essence as Boethius's luxuria, is a sentiment without which no man can be truly noble or complete." ${ }^{50}$ Love will ultimately transcend fate.

Underpinning Machaut's outlook on writing is the conviction that artistic creation must come from a place of joy, as he expresses in the Prologue:

Et s'on fait de triste matière

Si est joieuse la manière. 
And if it is done with sorrowful material, still the manner is joyous. (11. 43-44)

As Sylvia Huot explains in her discussion of the Prologue, "[a]s in the Consolation of Philosophy, then, the ideal is to develop a poetic discourse that will foster cheerful and optimistic sentiments, and a serene disposition." 51 Overall, the narrator of the Remede undergoes a change from sadness to joy. Like Boethius, he throws off his dependence on the whims of Fortune and puts his faith in his own ability to hope. For Huot the Remede "traces a movement from a poetics of desire [. . .] to one of hope," which is exemplified in the music. Desire, "with its emphasis on the isolation and deprivation of the poetic subject, leads to the breakdown of social bonds," something that can be seen in the music but also in the narrator's lack of engagement with his material and sonic environment. ${ }^{52}$ By contrast, hope, "with its emphasis on plenitude and fulfillment, allows for social interaction and cohesion," which we see in abundance by how delightfully absorbed in life the narrator becomes.

Yet we would be forgiven for wondering how this newfound joy in more prosaic and ephemeral details fits with the Boethian philosophy that Machaut incorporates. It would seem that there is a fundamental contradiction at play. Hope encourages the narrator to understand that "Le bien qu'on ne pert est milleur" ("The good you cannot lose is better," 1. 2455). This good is oneself and the lordship one has over oneself and one's reactions. Learning this and committing it to heart rescues the narrator from his intense melancholy and brings him joy. Why, then, should this also lead to greater attention being given to his environment? Surely, someone who has found self-sufficiency and Boethian serenity would not trouble himself with the bustling details of a meal's preparation, let alone take joy in such things? The answer lies in the manner of interaction. At the beginning of the tale, the narrator does reveal some anxiety about his surroundings. When he indicates in lines 763-770 that he was fortunate not to be overheard by other courtiers when reciting the lay, he betrays an intense concern in not only what they might think of him but how the environment itself could protect or betray him: they were in alcove, so he was somewhat shielded. Later, however, his shield is himself. He protects his feelings by not revealing them to the ladies with whom he speaks. When he approaches his lady after the banquet, he does so because he senses it is the right moment and comports himself "de maniere assez simplete" ("without any fuss," 1. 4030). It is not the physical location that gives him safety but his behavior. As such, his environment and its sounds can be enjoyed because they do not have a 
direct impact on his inner self. He can appreciate his world fully because he is self-sufficient; hence, his joyful description of the banquet preparations is not a contradiction of his use of Boethius but in keeping with the courtly reuse of Boethian philosophy as understood through the lens of the desire-hope opposition.

In some ways, the narrator's reconnection with the world and the sense of ease he displays within it seem as important as winning his lady's heart. His use of an environment that would be familiar to his readers (Hesdin and probably the manor house, too) tacitly underscores this. For all that love in literature is highly stylized, Machaut frequently seeks to point out that love also exists in a real, material, and recognizable world. (This idea receives its highest realization in the Voir dit.) We can imagine that there would be some comfort in this notion for his audience of courtiers dealing with their own love pains and intrigues. They may witness the poet healing poetically, but at the same time he heals in relation to a sonic and material environment that is authentic and familiar. This is a tale for those who might desire to cultivate their internal sufficiency and confidence but have every intention of living in the world and enjoying it.

Medievalists are notoriously defensive of their subject area. The use of the word medieval to describe anything considered backward, oppressive, unsophisticated, or underdeveloped is a source of constant irritation. We therefore take delight in sharing literature and music that is eloquent, complex, and thoughtful. The Remede is an ideal example of a work of art that is highly refined in its use of themes and styles but that also evinces a deep appreciation of the effects of emotional distress and its potential remedies. There are many ways to read the Remede, and the pleasure is in finding the skillful ways in which Machaut wove together the various tropes and concepts. Appreciating how the soundscape and material environment are employed to tell the narrator's emotional journey is one more aspect we can enjoy, and it fits well with other ways of understanding the Remede. This appreciation may also give us additional clues to broader ideas with which Machaut had to contend: how emotional distress was understood and the reception of his work.

That the remedy for emotional turmoil is offered by an allegorical figure could be read as a suggestion that the narrator in fact has come to terms with his distress and anxiety on his own. However, I do not believe that the introduction bears this out. The suggestion from the very outset of the Remede is that learning and growth take place in dialogue with a teacher. Lady Hope is not merely an allegory but an archetype 
of any wise or compassionate educator. Without such a guide, an individual might decline into the kind of nervous excursus exemplified by the complaint. And while there may not have been the terminology or formal structures of counseling in the Middle Ages, medieval people understood the significance of talking to and listening to an expert. In this regard, Lady Hope embodies the epitome of wisdom on the subject of curing melancholy. Further, this kind of emotional maturation was an ongoing process: in a moment of anxiety, Machaut's narrator invokes Hope again to give him additional support. Asking for help can thus be viewed as a sign of strength and growth. Yet this is tempered with an understanding of what is socially appropriate: the narrator's beloved warns of excessive sharing of feelings:

Et aussi vient souvent contraire

De parler quant on se doit taire,

Car on dist que trop parler cuit.

Moreover, words often give offense

When silence is what's called for,

For too much talk is a mistake. (11. 3779-3781)

Machaut paints a recognizable picture of the cognitive load of sadness and distress. The details of the sounding and material environment and the responses they provoke demonstrate a sophisticated view of the human mind under stress. Hesdin's attractions, unique and aimed at an elite audience, do not initially tempt the narrator to wax lyrical; instead, he foreswears those delights in favor of a secluded fountain in an overgrown and unvisited spot. But when his mind is freed from melancholy, even the sounds of the kitchen are a source of joy.

This may lead us to question further how soundscape is employed in relation to emotion. Kay has noted Donatus's twofold division of voice into distinct (that is, capable of being written) and confused (incapable of being written) and the further division into articulate and nonarticulate (meaningful or nonmeaningful). She discusses this in relation to the soundscape of troubadour lyric and whether song is human. Machaut's Remede contains sounds that are capable of being written-speech, music - and those that are not—moans, sighs—but are any sounds truly nonarticulate? Read through the lens of the emotional journey of the narrator, all sound has meaning. Biophonic and anthropic sounds, such as bubbling fountains or tables scraped on floors, may be, in the literal sense, nonarticulate. Yet as an extension and reflection of the narrator's mood, they acquire a deep significance, suggesting that his identity is constructed in relation to his environment. 
Machaut was deeply concerned with the reception and use of his work. McGrady has discussed his anxiety over a potentially interfering audience, and Jacqueline Cerquiglini-Toulet has remarked on his inclination to compile his work in collections. ${ }^{53}$ As a summa of love lyrics, there is in the Remede an implicit critique of the social function of music. Less is indeed more. While we can marvel at the virtuosity of the lay (both as a composition and a performance that requires a twooctave range) and the beauty of the complaint's melody, the suggestion is that these are less communal and perhaps less palatable to some audiences. Both are associated with the narrator's repetitive declamation of his woes and his isolation from human contact. Perhaps Machaut had received feedback from fellow courtiers about their preferred styles and the Remede is a nod toward their tastes that would have garnered wry smiles in return. Leach suggests that this "deliberately tedious" piece may even have been "darkly amusing" to an audience. ${ }^{54}$ Similarly, Huot has dubbed the lay "languorous" and the complaint "mournful," and Mark T. Rimple views the complaint as "rambling." 55 Whether or not medieval listeners got the joke or just found it dull, it is, to employ coding terminology, an anti-example: an aural illustration of both excessive melancholy and bad composition. By contrast, the shorter pieces in the latter half of the story (which also mostly demonstrate the new ars nova style) complement rather than dominate the narrative. One could link this more generally to what is expected within a social soundscape. Just as the lady objects to too much talk, music has its place.

Medievalists in recent decades have paid more attention to the role of the sounding and material environment in both historical and musico-poetic contexts. While material analyses have been prevalent, soundscape is a more recent phenomenon within the field. Work has been done focusing on the significance of the portrayal of sound, as witnessed by the contributions of Dillon, Kay, and others. However, there is more to be explored with the regard to the relationship between descriptions of sounding environment, literary meaning, and emotion in the works of both Machaut and his contemporaries.

$*$

At the time I wrote the first draft of this essay, the people of Great Britain were in lockdown due to the Covid-19 outbreak. Every Thursday at 8 p.m., they would throw open their doors and windows to clap, cheer, sing, and play instruments in support of National Health Service workers and other essential people who were making our lives safe and toler- 
able: caregivers, veterinarians, supermarket delivery drivers, and refuse collectors (to name but a few). I could not help but use the Remede as a lens through which to see the role of sound in our environment and our emotional lives. The cacophony connected us as audience and participants. Rather like the Remede, there were musical elements to this, but it was so much more. The sound carried a message far beyond the walls of our individual homes, reaffirming a landscape within post-industrial northwestern England as a community and transforming our individual lives into a network. We also reaffirmed ourselves, detached as we had been from much of our physical and social environment; the sound and movement and our ability to perceive it became part of a ritual of wellbeing and self-care. I sounded a ragged note on a replica Tibetan prayer horn, and someone in the next street of Victorian terraces responded with a trombone. We were transposed through the alchemy of sounding objects in space, from sadness to joy. But the sound obscured things, too. It drew focus from a health service in crisis, from hardworking people in danger who were not being paid enough, from those too lonely and too tired to join in. The noise covered the lack of noise: no children in the schoolyards, no busy feet and chatter of students in lecture theaters, no revelers leaving pubs. Eventually, as we realized what we were not noticing, the sounds of clapping and cheering fizzled out.

\section{Notes}

1. This essay arose from a class I taught in 2014 and 2015 at Johns Hopkins University, "Guillaume de Machaut: Exploring Medieval Authorship in the Digital Age," in which we explored the psychology of the narrator in Machaut's Remede de Fortune. I would like to thank my students for our enjoyable and enlightening discussions. I presented versions of this essay during sessions of the International Machaut Society at the International Medieval Congress (Western Michigan University, 2015) and at the In Conversation seminar series (University of Central Lancashire, 2019). I am grateful to the participants for their generous and helpful comments. I also extend heartfelt thanks to my colleagues Robert G. Lee and Laura Ridings at the University of Central Lancashire for listening to ideas and offering digital support. Finally, I wish to thank the two anonymous reviewers of this essay, whose insightful and invaluable observations were expressed with kindness.

2. We sometimes refer to these stylized amorous interactions as courtly love or by the medieval phrase fin'amors. I, however, avoid using courtly love because it is an anachronism that attempts to encapsulate a putative set of codified behaviors that dictate the interactions of aristocratic paramours. In reality, the portrayal of love in medieval literature is deeply complicated mosaic of compet- 
ing and contradictory demeanors and mores. For more on the origin and nature of the term courtly love and discussions of love in medieval literature, see, for example, Hult, "Gaston Paris"; and Kay, "Courts, Clerks, and Courtly Love."

3. To explore Machaut's manuscripts, visit the website of the International Machaut Society (http://www.machautsociety.org). Of the Remede manuscripts, only Machaut MS FP (Florence, Biblioteca Nazionale Centrale, Panciatichiano 26 (MS FP) does not appear to be digitized. The digital facsimile of Paris, Bibliothèque nationale de France, MS fr. 843 (MS M) is a black-and-white copy of the microfilm.

4. Kay and Noudelmann, "Introduction," 8.

5. For a detailed examination of "sounding number" and the influence of Boethius on the Remede, see Rimple, "Hearing Boethius." To understand the relationship between music, rhetoric and the didactic nature of the Remede, see Stokes, "In Search."

6. Schafer, The Soundscape.

7. Ibid., 8.

8. Dillon, The Sense of Sound.

9. Ibid., 6 .

10. Ibid.

11. See, for example, Kay and Noudelmann, "Introduction."

12. Ibid., 5.

13. Hoffman, Nature.

14. Brownlee, Poetic Identity.

15. For discussions of citation and the significance of its use, see Plumley, The Art of Grafted Song; and Rose-Steel, "French Ars Nova Motets."

16. Palmer, "Guillaume de Machaut" 241.

17. See ibid.; and Palmer, "Authorial Second Lives."

18. McGrady, Controlling Readers.

19. Ibid., 48.

20. Edge, "Diagnosing the Past."

21. Godden and Hsy, "Encountering Disability," p. 316.

22. Modern readers often feel a disjunction when considering medieval theories of emotion, yet we can draw parallels. For example, Moore's essay in this issue considers the erotics of grief, presenting a form of desire that was reserved for elites, which she calls "emotional exceptionalism." While this may seem alien to modern sensibilities, which view grief as "full of sadness and aversion," Moore draws parallels between the eroticizing of grieving women and the outputs of modern pop culture in which cyborgs and artificial intelligence are constructed in relation to human desire and domination.

23. Cohen-Hanegbi, “A Moving Soul," 50.

24. U.S. National Library of Medicine, "Emotion and Disease."

25. Machaut, Complete Poetry and Music, 2. Line references from this edition are cited parenthetically in the text. 
26. See, for example, Peraino, Giving Voice to Love, 235; Butterfield, Poetry and Music, 217; and Hoepffner, "Introduction," xiv. Enders discusses how memorizing Hope's teachings has not only aided the lover in recovering his confidence but also has returned his ability to compose ("Music, Delivery, and the Rhetoric of Memory," 456).

27. The lay has 250 lines and the complaint 576 . The first direct speech is in line 1,608, uttered by Lady Hope.

28. I am excluding the prayer from this count as it is not notated.

29. Peraino discusses the possibility that "a lyrical poem with a refrain and an origin in public dance songs could be a complete expression as read-without musical performance" (Giving Voice to Love, 259). While Peraino is focusing here on refrain songs with a basis in dance, we might question whether the lay can be understood as being read rather than sung and that this may have been an acceptable mode of performance. Swift makes an interesting point that music may be a more truthful form of emotional expression. In both Voir dit and the Remede Machaut "affirms that true lyric expression entails no feigning: 'Car de sentiment ne fait, / Son oeuvre et son chant contrefait' ('For whoever does not write with feeling, counterfeits his deed and song,' Remede de Fortune, 11. 407-8)." In this couplet, Swift notes, Machaut emphasizes song (chant); hence, "it may be that a nonlinguistic, musical means of expression is precisely what enables truthful emotional expression rather than words" ("The Poetic I," 28). If the narrator is reading rather than singing, this fits with his desire to mask his true feelings from the lady. Enders views the Remede as "a work that may then be read as extended metacommentary on the traditional commingling of declamation and song" ("Music, Delivery, and the Rhetoric of Memory," 453). The narrator's issues stem from his lack of education in the memorial arts, making him a callow and insecure composer and lover. In this regard, the most important issue is not whether the songs be read or sung, or even whether they are typically performed, but whether the narrator can remember and internalize the musical, poetical, and rhetorical lessons of Lady Hope.

30. The miniature in Paris, Bibliothèque nationale de France, MS fr. 1586 (MS C), fol. 28v, gives this scene an added dimension. The narrator is depicted reading to the lady from a scroll. In contrast to the didactic edicts of the opening lines of the Remede, he has not committed the song to memory and the scroll appears to be a barrier between them.

31. I am aware of only one recording of the complaint in its entirety, sung by Marc Mauillon (Mauillon et al., Guillaume de Machaut). Mauillon mitigates some of the problems of singing for such a period of time. His version of the complaint is accompanied by flute, vielle, and harp, which support the vocal line and provide brief interludes. He also choses to speak a third of the stanzas, allowing him to rest his voice, execute those stanzas more quickly, and add a wider range of mood and timbre to the performance. Even with these spoken sections, the whole track lasts for nearly forty-five minutes, and the listener becomes acutely aware of the unvaried nature of the music even with the skilled decoration of the musicians and the different timbres of the instruments. 
32. Leach, Guillaume de Machaut, 229. Leach further notes that "the more ethically focused artistic culture of the Middle Ages would probably have allowed such a deliberately tedious performance-perhaps even found it darkly amusing-on account of its instructive purpose within a deeply didactic dit" (ibid.).

33. Enders remarks that this ballade is "an intriguing literary puzzle" ("Music, Delivery, and the Rhetoric of Memory," 455). It is physically impossible for Hope to sing the polyphony; however, when viewed as "an exemplum of memory theory," with Hope becoming a "mnemonic vision" for the entranced narrator, we can imagine this taking place in his mind (ibid.).

34. Peraino, Giving Voice to Love, 238. See also Calin, A Poet at the Fountain, 63.

35. Peraino notes that Machaut may be taking "poetic license" by characterizing this virelai as a dance song because it does not have a regular metrical structure (Giving Voice to Love, 244-445).

36. Enders, "Music, Delivery, and the Rhetoric of Memory," 454.

37. Truitt, Medieval Robots, 124.

38. Ibid., 128.

39. Truitt does note that Machaut MS C contains an accurate depiction of a crank in the Remede detailing Fortune's wheel (ibid., 129-130). While Machaut did not describe machinery, it is evoked in an image that appears beneath a miniature of Machaut composing his complaint in the park (fol. 30v).

40. Enders, "Music, Delivery, and the Rhetoric of Memory," 453.

41. Farmer, "Aristocratic Power."

42. Ibid., 650. Farmer estimates that during the time of Robert II of Artois there could have been as many as 1,000 fallow deer in the park. See Wierdijk for an example of the burling of male fallow deer.

43. Farmer, "Aristocratic Power," 662. See "Grey Heron” for an example of heron cries.

44. Truitt, Medieval Robots, 117.

45. Calin notes how the lady is transformed from an object of worship to someone with her own personality (A Poet at the Fountain, 64).

46. Dillon, The Sense of Sound, 93.

47. See Rose-Steel, "French Ars Nova Motets," 134-136; and Palmer, "Guillaume de Machaut," 250-256.

48. Beer, "Desire in a Good Mood," 18.

49. Calin, A Poet at the Fountain, 61.

50. Ibid.

51. Huot, "Poetry of Consolation," 170.

52. Ibid., 172.

53. See McGrady, Controlling Readers; and Cerquiglini-Toulet, The Color of Melancholy, chap. 5.

54. Leach, Guillaume de Machaut, 229.

55. Huot, "Poetry of Consolation," 172; Rimple, "Hearing Boethius," 31. 


\section{Works Cited}

Beer, Lewis. "Desire in a Good Mood: The Ambivalence of Hope in the Remede de Fortune." Nottingham Medieval Studies 58 (2014): 155-183. https:// doi-org.proxy01.its.virginia.edu/10.1484/J.NMS.5.103266.

Boethius, Anicius Manlius Severinus. The Consolation of Philosophy, translated by David R. Slavitt. Cambridge, MA: Harvard University Press, 2008. http:// ebookcentral.proquest.com/lib/uclan-ebooks/detail.action?docID=3300011.

Brown, Brian, Peter Rutherford, and Paul Crawford. "The Role of Noise in Clinical Environments with Particular Reference to Mental Health Care: A Narrative Review." International Journal of Nursing Studies 52, no. 9 (2015): 1514-1524. https://doi.org/10.1016/j.ijnurstu.2015.04.020.

Brownlee, Kevin. Poetic Identity in Guillaume de Machaut. Madison: University of Wisconsin Press, 1984.

Butterfield, Ardis. Poetry and Music in Medieval France: From Jean Renart to Guillaume de Machaut. Cambridge: Cambridge University Press, 2002.

Calin, William. A Poet at the Fountain: Essays on the Narrative Verse of Guillaume de Machaut. Lexington: University Press of Kentucky, 2015.

Cerquiglini-Toulet, Jacqueline. The Color of Melancholy: The Uses of Books in the Fourteenth Century, translated by Lydia G. Cochrane. Baltimore: Johns Hopkins University Press, 1997.

Cohen-Hanegbi, Naama. "A Moving Soul: Emotions in Late Medieval Medicine.” Osiris 31, no. 1 (2016): 46-66. https://doi.org/10.1086/687558.

Dillon, Emma. The Sense of Sound: Musical Meaning in France, 1260-1330. Oxford: Oxford University Press, 2012.

Earp, Lawrence. Guillaume de Machaut: A Guide to Research. New York: Garland, 1995.

Edge, Joanne. "Diagnosing the Past." Wellcome Collection, September 26, 2018. https://wellcomecollection.org/articles/W5D4eR4AACIArLL8.

Enders, Jody. "Music, Delivery, and the Rhetoric of Memory in Guillaume de Machaut's Remède de Fortune." PMLA 107, no. 3 (1992): 450-464. https://doi.org/10.2307/462754.

Farmer, Sharon. "Aristocratic Power and the 'Natural' Landscape: The Garden Park at Hesdin, ca. 1291-1302.” Speculum 88, no. 3 (2013): 644-680. https://www.jstor.org/stable/43576781.

Godden, Richard and Jonathan Hsy. "Analytical Survey: Encountering Disability in the Middle Ages." New Medieval Literatures 15 (2013): 313-339. https://doi.org/10.1484/J.NML.5.103458.

Green, Richard Firth. "Le Roi Qui Ne Ment and Aristocratic Courtship." In Courtly Literature: Culture and Context. Proceedings of the Fifth Triennial Congress of the International Courtly Literature Society, edited by Keith Busby and Erik Kooper, 211-225. Dalfsen, The Netherlands: Utrecht Publications in General and Comparative Literature, 1986. 
"GreyHeron.” British-birdsongs.uk, https://www.british-birdsongs.uk/grey-heron /?type684.

Hoepffner, Ernest. "Introduction: 1. Remede de Fortune." In Euvres de Guillaume de Machaut, volume 2, edited by Ernest Hoepffner. Paris: Société des Anciens Textes Français, 1911.

Hoffman, Jascha. “Q\&A Bernie Krause: Soundscape Explorer.” Nature 485, no. 7398 (17, 2012): 308. https://search.proquest.com/docview/1017604116?a ccountid $=17233$.

Hult, David F. "Gaston Paris and the Invention of Courtly Love." In Medievalism and the Modernist Temper, edited by R. Howard Bloch and Stephen G. Nichols, 192-224. Baltimore: Johns Hopkins University Press, 1996.

Huot, Sylvia. "Guillaume de Machaut and the Consolation of Poetry." Modern Philology, vol. 100, no. 2 (2002): 169-195. https://doi.org/10.1086/493179.

International Machaut Society. http://www.machautsociety.org.

Kay, Sarah. "Courts, Clerks, and Courtly Love." In The Cambridge Companion to Medieval Romance, edited by Roberta L. Krueger, 81-96. Cambridge: Cambridge University Press, 2006.

—. "Touching Singularity: Consolation, Philosophy, and Poetry in the French Dit." In The Erotics of Consolation: Desire and Distance in the Late Middle Ages, edited by Catherine E. Léglu and Stephen J. Milner, 21-38. New York: Palgrave Macmillan, 2008.

Kay, Sarah, and François Noudelmann. "Introduction: Soundings and Soundscapes.” Paragraph, vol. 41, no. 1 (2018): 1-9. https://doi.org/10.3366/ para.2018.0246.

Leach, Elizabeth Eva. Guillaume de Machaut: Secretary, Poet, Musician. Ithaca, NY: Cornell University Press, 2014.

Machaut, Guillaume de. The Complete Poetry and Music. Volume 2, The Boethian Poems, edited and translated by R. Barton Palmer, music edited by Uri Smilansky. Kalamazoo, MI: Medieval Institute Publications, 2019. https://d.lib.rochester.edu/teams/publication/ guillaume-de-machaut-complete-poetry-and-music-volume2.

- The Fountain of Love (La fonteinne amoureuse) and Two Other Love Vision Poems, edited and translated by R. Barton Palmer. New York: Garland, 1993.

- Le Livre dou Voir Dit: The Book of the True Poem, edited by Daniel Leech-Wilkinson and translated by R. Barton Palmer. New York: Garland, 1998.

- Prologue. In The Fountain of Love (La fonteinne amoureuse) and Two Other Love Vision Poems, edited and translated by R. Barton Palmer, 1-19. New York: Garland, 1993.

Mauillon, Marc, Vivabiancaluna Biffi, Serge Goubioud, Emmanuel Vistorky, Angélique Mauillon, and Pierre Hamon. Guillaume de Machaut: Le Remède de Fortune. Eloquentia, 2009. Amazon Music. 
McGrady, Deborah. Controlling Readers: Guillaume de Machaut and His Late Medieval Audience. Toronto: University of Toronto Press, 2006.

Palmer, R. Barton. "Authorial Second Lives: Machaut, Chaucer, and Philip Roth." In Machaut's Legacy: The Judgment Poetry Tradition in the Later Middle Ages and Beyond, edited by R. Barton Palmer and Burt Kimmelman, 271-296. Gainesville: University Press of Florida, 2017.

—. "Guillaume de Machaut and the Classical Tradition: Individual Talent and (Un)Communal Tradition." In A Companion to Guillaume de Machaut, edited by Deborah McGrady and Jennifer Bain, 241-260. Boston: Brill, 2012.

Peraino, Judith A. Giving Voice to Love: Song and Self-Expression from the Troubadours to Guillaume de Machaut. Oxford: Oxford University Press, 2011.

Plumley, Yolanda. The Art of Grafted Song: Citation and Allusion in the Age of Machaut. Oxford: Oxford University Press, 2013.

Rimple, Mark T. "Hearing Boethius in the Music and Rhetoric of Guillaume De Machaut." Carmina Philosophiae 19 (2010): 25-48. www.jstor.org/ stable/44078609.

Rose-Steel, Tamsyn. "French Ars Nova Motets and Their Manuscripts: Citational Play and Material Context." PhD diss., University of Exeter, 2011.

Schafer, R. Murray. The Soundscape: Our Sonic Environment and the Tuning of the World. Rochester, VT: Destiny, 1994.

Stokes, Jordan. "In Search of Machaut's Poietics: Music and Rhetoric in Le Remede de Fortune." Journal of Musicology, vol. 31, no. 4 (2014): 395-430. doi:10.1525/jm.2014.31.4.395.

Swift, Helen. "The Poetic I." In A Companion to Guillaume de Machaut, edited by Deborah McGrady and Jennifer Bain, 15-32. Boston: Brill, 2012.

Truitt, Elly R. Medieval Robots: Mechanism, Magic, Nature, and Art. Philadelphia: University of Pennsylvania Press, 2015. https://ebookcentral.proquest. com/lib/uclan-ebooks/detail.action?docID=3442519.

University of Exeter. "The Works of Guillaume de Machaut: Music, Image, Text in the Middle Ages." http://machaut.exeter.ac.uk.

U.S. National Library of Medicine. "Emotions and Disease." https://www.nlm. nih.gov/exhibition/emotions/balance.html

Wierdijk. "Vocal Fallow Deer." YouTube. October 20, 2012. https://www.youtube.com/watch?v=75LkMg5C1ks. 